\title{
The influence of the coagulant PAX-18 on Planktothrix agardhii bloom in a shallow eutrophic fishpond
}

\author{
Eva Lelková ${ }^{1}$, Martin Rulík ${ }^{2}$, Petr HekerA ${ }^{2}$, Pavel Dobiáš ${ }^{3}$, Petr Dolejš ${ }^{3}$, Marcela \\ BorovičKovÁ ${ }^{3} \&$ AloISIE PoulíčKovÁ ${ }^{1 *}$
}

\author{
${ }^{1}$ Department of Botany, Faculty of Science, Palacký University Olomouc, tř. Svobody 26, CZ-771 46 Olomouc, \\ Czech Republic, * corresponding author, e-mail: aloisie.poulickova@upol.cz \\ ${ }^{2}$ Department of Ecology and Environmental Sciences, Faculty of Science, Palacký University Olomouc, Šlechtitelu \\ 11, CZ- 78371 Olomouc, Czech Republic \\ ${ }^{3}$ W\&ET Team, Water and Environmental Technology Team, Písecká 2, box 27, CZ-370 11 České Budějovice, \\ Czech Republic
}

\begin{abstract}
For the first time in the Czech Republic, the PAX-18 coagulant has been used to restore a eutrophic fishpond. The polyaluminium hydrochloride coagulant was applied repeatedly to a shallow eutrophic fishpond in spring 2005. Two cylindrical plastic enclosures were used to isolate parts of the pond as untreated controls. Selected environmental variables were measured in situ. Water samples were analyzed regularly for nutrients, chlorophyll $a$ concentration and phytoplankton abundance and structure with special focus on Planktothrix agardhii. The PAX18 treatment led to a marked increase in the N/P ratio and changes in the structure and abundance of phytoplankton in the fishpond and P. agardhii blooms were eliminated in the fishpond. By contrast, P. agardhii dominated the phytoplankton in the control enclosures, as it had in the fishpond in 2004, prior to the PAX-18 treatment.
\end{abstract}

Key words: shallow lakes, phosphorus precipitation, restoration, aluminium treatment, cyanobacterial water blooms, phytoplankton

\section{Introduction}

Fishponds are man-made shallow water bodies in which water level, fish stock and to some extent, nutrient inputs are under human control (KoŘíneK et al. 1987). They represent the most common type of the stagnant water biotopes in the Czech Republic. During the past few decades, the original oligotrophic or mesotrophic character of the fishponds has changed to eutrophic, and even hypertrophic, conditions. Eutrophication is a result of intensified management for fishproduction, changes in agriculture practices in the catchment area, and use of some fishponds as wastewater recipients. Eutrophication is the most widespread form of fishpond pollution and has many deleterious impacts on aquatic systems. In addition to increasing overall primary production, eutrophication causes considerable changes in biochemical cycles and biological communities. For example, the decrease in $\mathrm{N} / \mathrm{P}$ ratio that is usually associated with eutrophication often results in primary production shifting from primarily diatoms, and other small edible algae, towards larger cyanobacteria that are stronger competitors for nitrogen and more resistant to grazing (SмITH 1983). Moreover, cyanobacteria are producers of secondary metabolites, cyanotoxins.

Restoration methods such as phosphorus precipitation, aeration, sediment treatment and sediment removal have all been used to counteract internal loading of nutrients (STRAŠKRABA 1986), whilst biomanipulation is the most common restoration method today (MEHNER et al. 2001). The phosphorus inactivation method has been practised in many lakes using aluminium or iron compounds (WoLTer 1994). Aluminium coagulants are considered to be more efficient, Al-chlorides should be preferred prior to Alsulphates when applying $\mathrm{Al}$ to lake sediments because it is important not to immobilize iron by sulphide precipitation (HANSEN et al. 2003). Recently, a "new generation" of aluminium coagulants have appeared on the Czech market. These are polyaluminium chlorides distributed by Kemwater ProChemie under the trade name PAX. 
One of them is PAX-18 (9\% Al), a coagulant commonly used in water and wastewater treatment. It is also suitable for phosphorus precipitation and removal of filamentous bacteria in sewage treatment plants.

The aim of this study was to examine the effect of PAX-18 on selected environmental variables and on the phytoplankton community. The main goal of the restoration was to eliminate cyanobacterial water blooms. It was the first time this kind of coagulant had been used for the treatment of a whole fishpond in the Czech Republic.

\section{Material and methods}

The studied fishpond is situated in the Forest Garden in the village of Bílá Lhota, near Olomouc (Central Moravia, the Czech Republic). It has a total area of $1540 \mathrm{~m}^{2}$ and a maximum depth of $1 \mathrm{~m}$. Approximately $65 \%$ of the surface area is shaded by surrounding vegetation. Although leaf litter from surrounding trees contributes to the sediment accumulation, the main source of eutrophication is intensive agriculture in surrounding fields and untreated sewage waters from the village of Bílá Lhota (HAŠLER \& POULíčKová 2003). By contrast to other ponds (LySÁKOvÁ et al. 2007) Bílá Lhota has relatively high conductivity. The fishpond is not used for fish production and served as a wastewater recipient until 2004. The fishpond has relatively high conductivity $\left(351-599 \mu \mathrm{S} . \mathrm{cm}^{-1}\right)$ and nutrient concentrations ( $\mathrm{TP}=0.21-0.77 \mathrm{mg} \cdot \mathrm{l}^{-1}$, $\left.\mathrm{NO}_{3}^{-}=0.2-4.86 \mathrm{mg} .1^{-1}, \mathrm{NH}_{4}^{+}=0.54-3.6 \mathrm{mg} .1^{-1}\right)$. As a result of eutrophication, a layer of muddy, putrescent sediments accumulated on the bottom of the fishpond. The phytoplankton community is dominated by the filamentous cyanobacterium Planktothrix agardhii (up to $90 \%$ ) from May to November, along with a mixture of euglenophytes and green algae.

The fishpond was dosed repeatedly with the PAX-18 coagulant on 13 April, 4 May, 13 June and 20 June 2005, 600 kilograms was used altogether. The first dose equalled $200 \mu \mathrm{mol} \mathrm{Al} .1^{-1}$ and the next three doses equalled $350 \mu \mathrm{mol} \mathrm{Al} . \mathrm{l}^{-1}$. Dosing of the coagulant was based on in situ experiments performed in 2004 (LeLKOví et al. 2005) and laboratory coagulation tests. The coagulant was applied evenly on the whole surface of the fishpond from a storage bottle mounted on a small boat equipped with an electric engine. It was introduced about $20 \mathrm{~cm}$ below the water surface and vortexed by the propeller.

Two cylindrical clear and colourless PE enclosures $(120 \mathrm{~cm}$ in length and $100 \mathrm{~cm}$ in diameter) placed into the bottom sediment were used as controls. Each enclosure was open at the bottom and top and bounded the water column from the bottom to the surface, protecting it from diffusion of ions and algal infiltration. Secchi transparency, conductivity, $\mathrm{pH}$, temperature, oxygen concentration and saturation were measured regularly in the fishpond and in the control enclosures using mobile instruments (WTW company). All the variables were measured at a fixed position and fixed time of day (in the morning) in the fishpond and in the control enclosures. Mixed water samples were taken regularly from the water column with a Plexiglass tube ( $1 \mathrm{~m}$ in length) from the fishpond and control enclosures from April to August 2005. Concentrations of phosphate, nitrate, amonium and chloride ions, total phosphorus and total nitrogen were checked with a HACH DR 2000 spectrophotometer (ANONYMOus 1992). Concentrations of aluminium were assessed spectrophotometrically using pyrocatechol violet. Chlorophyll- $a$ was measured by extraction into an acetone-methanol mixture using a UV-VIS Super Aquarius CE 900 spectrophotometer (PeCHAR 1987). Phytoplankton species were identified in live material (after the centrifugation at $1500 \mathrm{rpm}$ for 10 minutes). The abundance of phytoplankton was carried out by counting of individuals or filament units (1 filament unit $=100 \mu \mathrm{m})$ in fixed samples ( $0.5 \%$ Lugol solution) in a Bürker chamber. 400 specimens (filament units) were counted in each sample. After each treatment, coagulation flocs were also observed under a light microscope. All results were evaluated using NCSS 2000 software. The repeated measures ANOVA was performed on means of two control enclosures and probability level was checked according to KIRK (1982).

\section{Results}

The direct influence of the coagulant on the chemical properties of water was indicated by increases in chloride and aluminium concentrations. The content of chlorides and conductivity in the fishpond increased after each treatment (cf. situation in the control enclosures) and gradually decreased two weeks after the final treatment (Tables 1,2). By contrast to the controls, aluminium concentration increased in the fishpond immediately after dosing, but it decreased to the original values within days (cf. Tables 1,2).

Despite the acidic properties of the polyaluminium chloride solution, its introduction to the fishpond had almost no impact on the water $\mathrm{pH}(\mathrm{F}=0.34, \mathrm{P}=0.574, \mathrm{DF}=12.25$, Repeated MeasuresANOVA, F-test with Geisser-Greenhaus Adjustments). A small $\mathrm{pH}$ decrease was observed only immediately after each addition of the coagulant, $\mathrm{pH}$ values increased again within days of each treatment. 


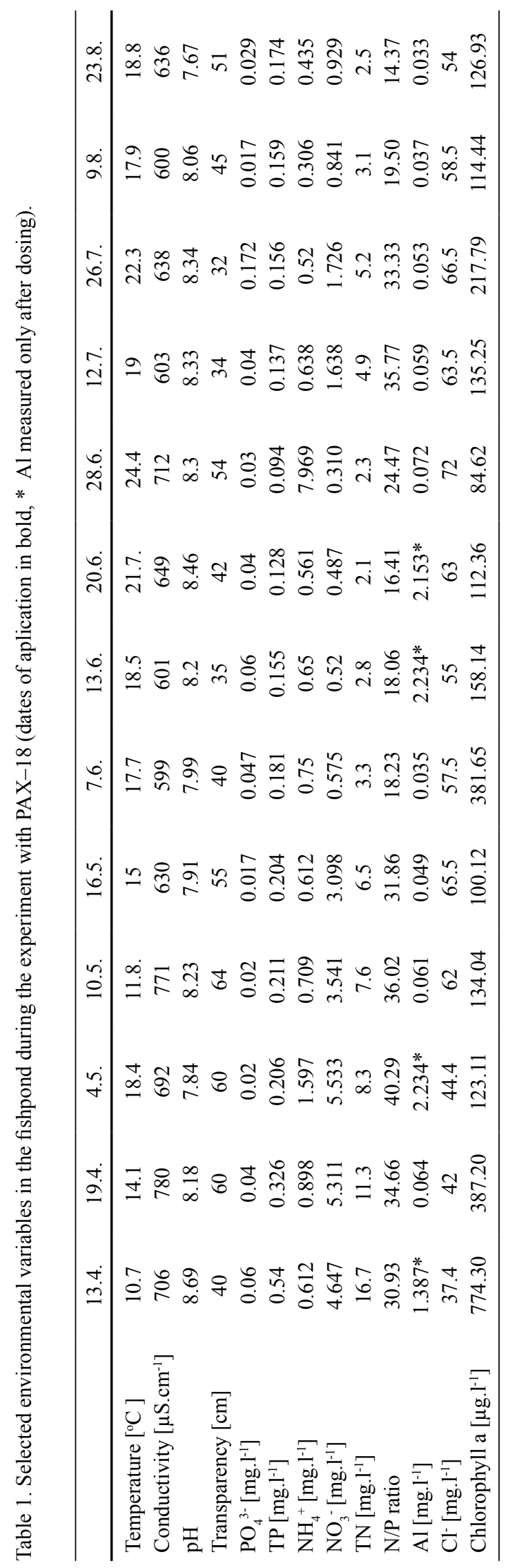

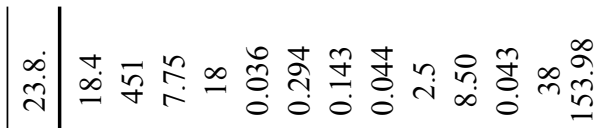
我

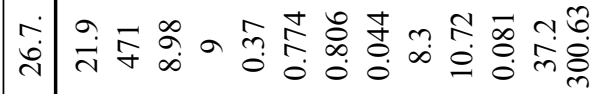

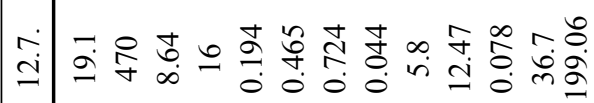
究

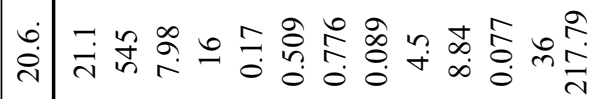

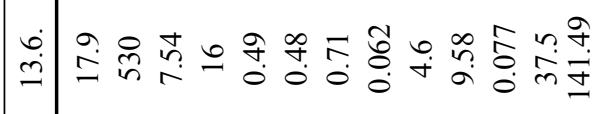
눈

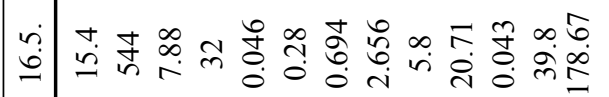

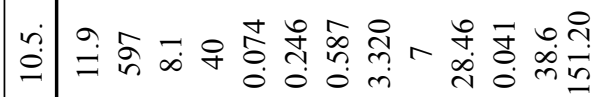
m.

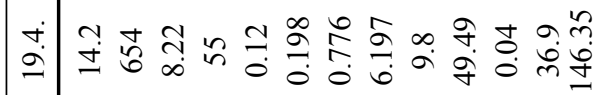

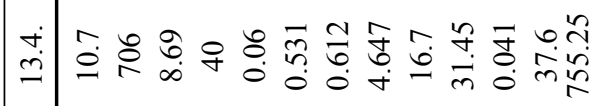

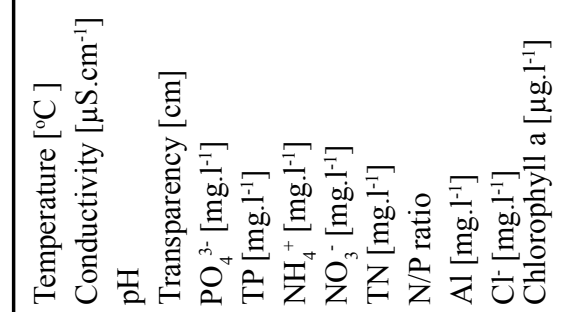




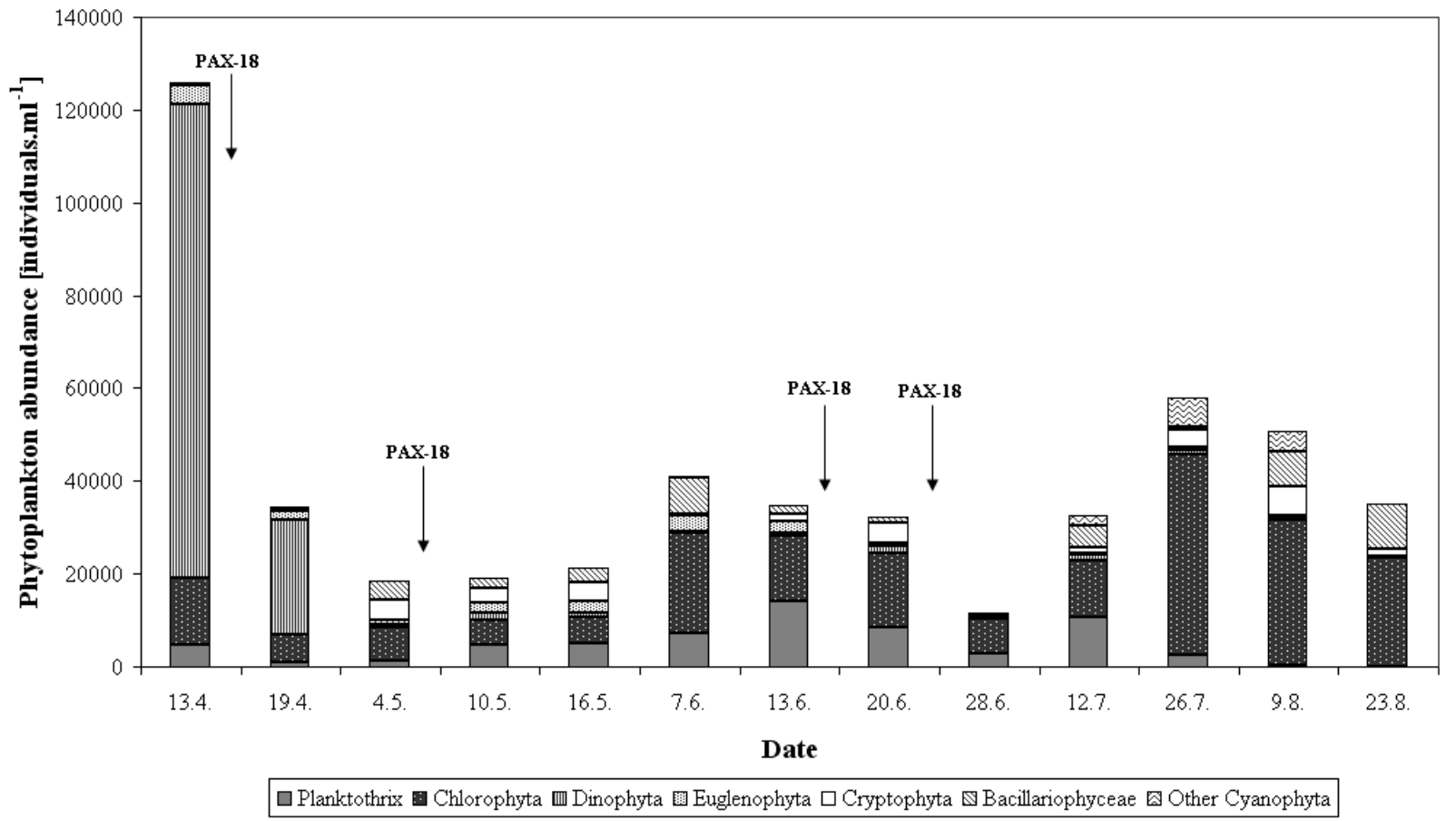

Fig. 1. The phytoplankton structure and abundance in the treated fishpond during the experiment in 2005 (arrows mark the PAX-18 treatment).

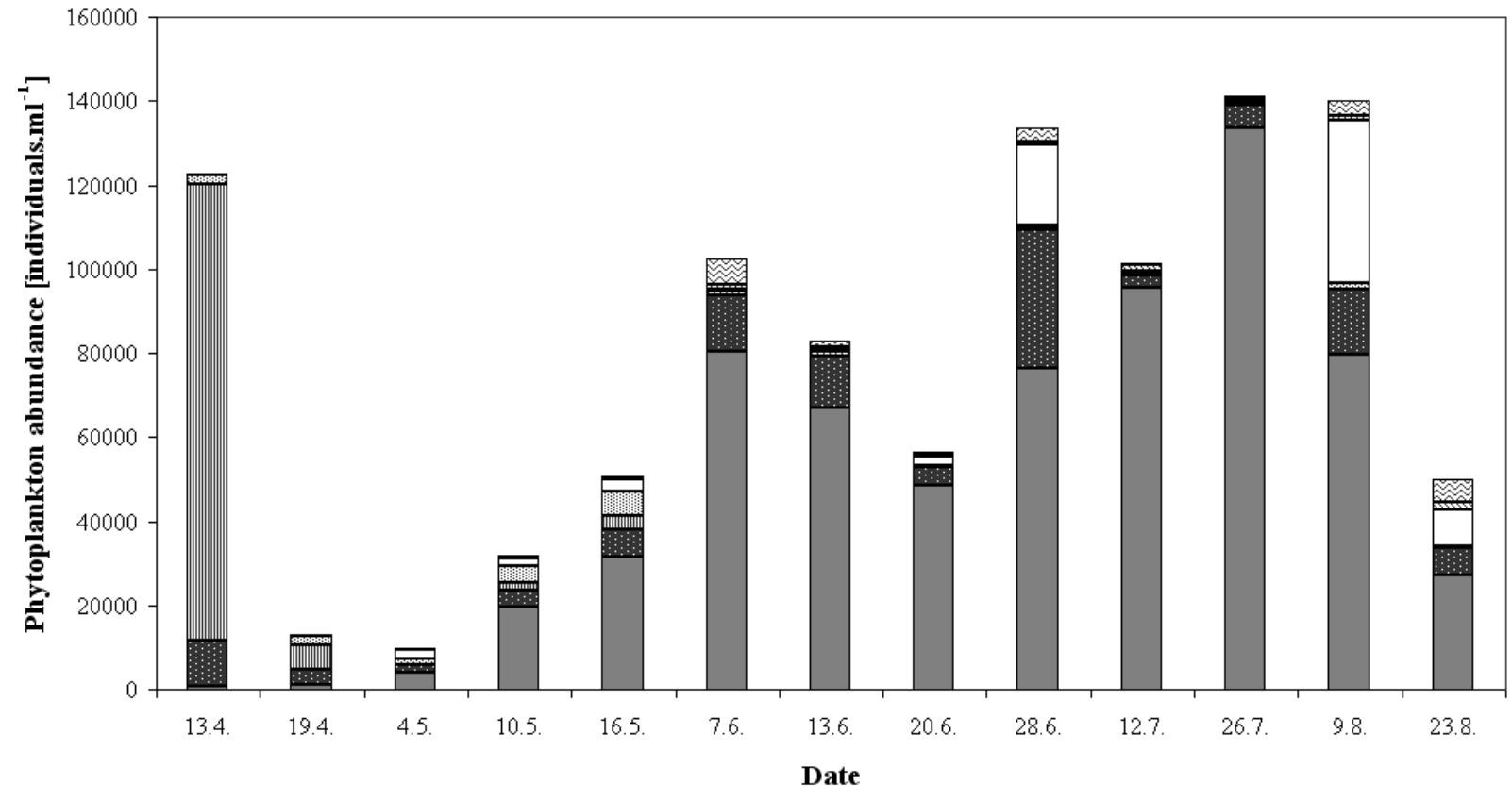

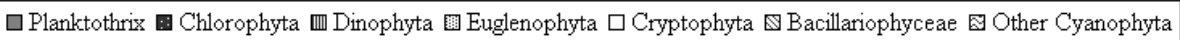

Fig. 2. The phytoplankton structure and abundance in the control enclosures (mean values) during the experiment in 2005. 
At the beginning of the experiment, the phosphate concentration in the fishpond water was $0.06 \mathrm{mg} . \mathrm{l}^{-1}$ and it was reduced after each application of the coagulant. Phosphate concentrations remained low during the whole sampling period (Table 1) as release from the bottom sediments was halted. The application of the coagulant had a major impact on the total phosphorus due to coagulation, aggregation and sedimentation of phytoplankton organisms and their removal from the water column. Entrapment of algal species and Planktothrix filaments into the flocs was observed immediately after dosing. The removal of phytoplankton organisms from the water column was well documented by water transparency which increased after each treatment in the fishpond (Table 1). In contrast, both phosphate concentration and total phosphorus in the control enclosures were high during the entire experiment. Water transparency in the control enclosures was low, with further decreases during the summer (Table 2).

There were significant differences between the fishpond and control enclosures in the N/P ratio $(\mathrm{F}=4.60, \mathrm{P}=0.007, \mathrm{DF}=12.25$, Repeated Measures ANOVA, F-test with Geisser-Greenhaus Adjustments). The ratio of $\mathrm{N} / \mathrm{P}$ in the fishpond water was higher than in the control enclosures from May onwards.

The PAX-18 treatment led to changes in the phytoplankton structure, abundance and chlorophyll- $a$ concentrations in the fishpond (Fig. 1, Table 1). Although, chlorophyll-a values in the fishpond were mostly lower than in the control enclosures (Tables 1,2), repeated measures ANOVA performed on chlorophyll- $a$ concentrations, revealed insigni-ficant differences between the fishpond and the control enclosures $(\mathrm{F}=2.06, \quad \mathrm{P}=0.112, \quad \mathrm{DF}=12.25, \quad \mathrm{~F}$-test with Geisser-Greenhaus Adjustments). On the other hand, phytoplankton abundance and number of $P$. agardhii filaments in the fishpond water differed considerably from those in the control enclosures (Figs. 2-4). There were also significant differences in the phytoplankton community structure and phytoplankton abundance between the fishpond and control enclosures (Table 3). In general, total phytoplankton abundance in the untreated enclosures was higher than 50000 individuals per $\mathrm{ml}$ from mid-May to August, while in the fishpond it did not exceed this level during this period (except of 16 June). Differences in phytoplankton abundance between the fishpond and control

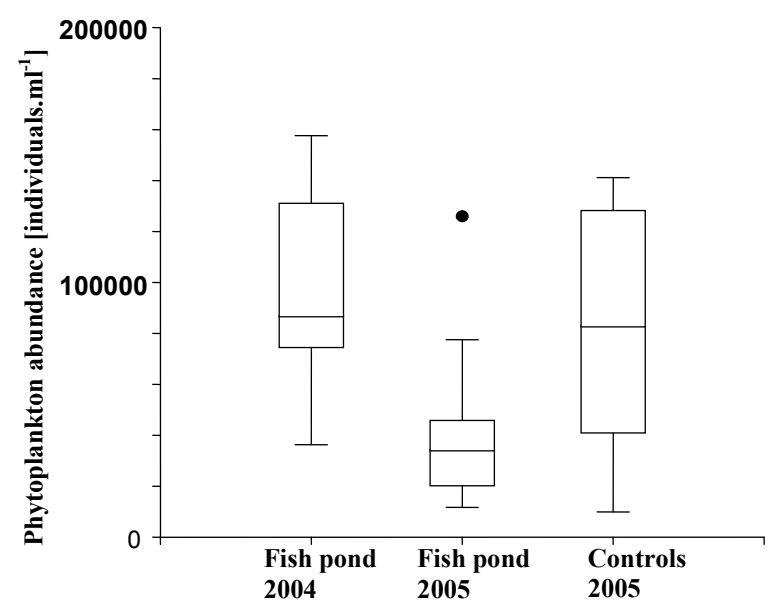

Fig. 3. Box-whisker plot: comparison of phytoplankton abundances in the fishpond in seasons 2004 (before treatment) and 2005 (after treatment) and untreated control enclosures.

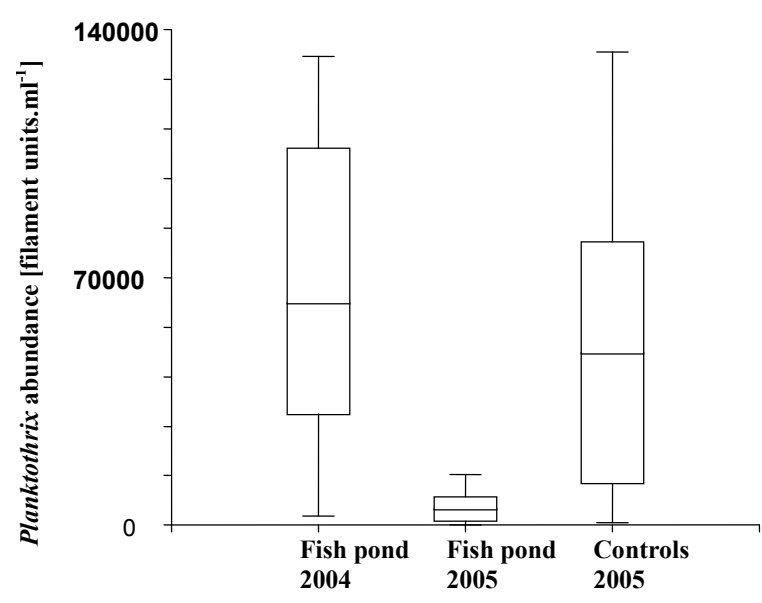

Fig. 4. Box-whisker plot: comparison of Planktothrix abundances in the fishpond in seasons 2004 (before treatment) and 2005 (after treatment) and untreated control enclosures (1 filament unit $=100 \mu \mathrm{m})$.

Table 3. Statistical comparison of the phytoplankton structure and total phytoplankton abundance between the fishpond and control enclosures (Repeated Measures ANOVA, F-test with Geisser-Greenhaus Adjustments).

\begin{tabular}{lccc}
\hline & $\mathrm{F}$ & $\mathrm{P}$ & $\mathrm{DF}$ \\
\hline Planktothrix & 13.26 & 0.003 & 12.25 \\
Chlorophyta & 6.5 & 0.025 & 12.25 \\
Dinophyta & 12.69 & 0.004 & 12.25 \\
Euglenophyta & 0.92 & 0.356 & 12.25 \\
Cryptophyta & 0.1 & 0.754 & 12.25 \\
Bacillariophyceae & 24.51 & 0.0003 & 12.25 \\
Other Cyanophyta & 0.29 & 0.597 & 12.25 \\
Total phytoplankton abundance & 11.11 & 0.006 & 12.25 \\
\hline
\end{tabular}




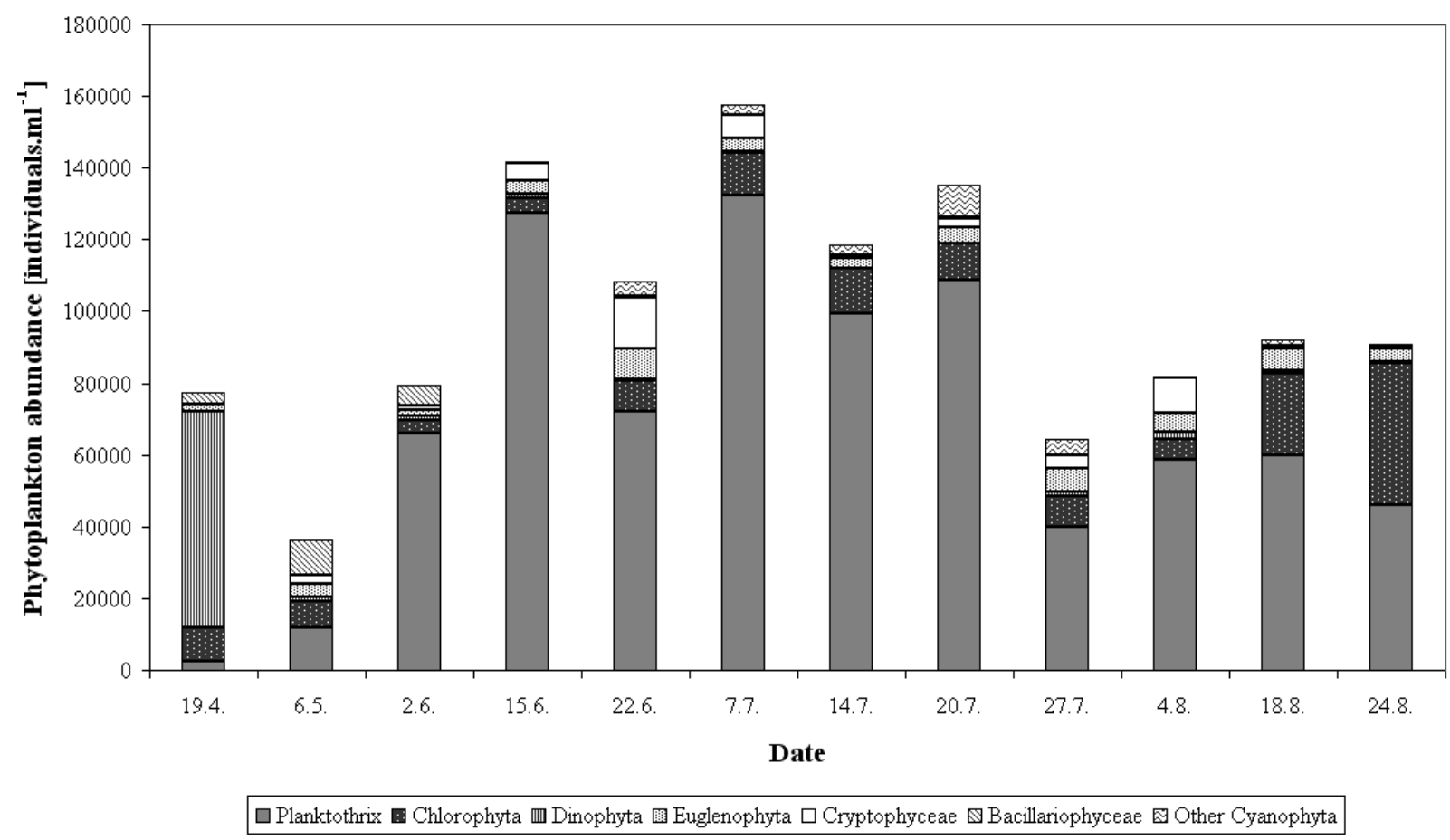

Fig. 5. The phytoplankton structure and abundance in the fishpond in 2004 (season before treatment).

enclosures were mainly caused by elimination of Planktothrix accompanied by a slight increase in chlorophytes, diatoms and phytoflagellates in the fishpond.

In total, 46 species of cyanobacteria and algae were identified in the fishpond and 35 in the control enclosures. Species richness in the control enclosures dominated by $P$. agardhii decreased gradually during the season. Phytoplankton composition in the treated fishpond shifted from the dominance of dinophytes in the spring to chlorophytes (Chlamydomonas, Scenedesmus, Monoraphidium, Micractinium, Actinastrum, Ankistrodesmus, Golenkinia, Coelastrum, Pediastrum, Kirchneriella, Chlorella), diatoms (Fragilaria, Nitzschia) and phytoflagellates (Euglena, Phacus, Trachelomonas, Cryptomonas). By contrast, the phytoplankton structure in the control enclosures changed rapidly from the dominance of dinophytes to dominance by Planktothrix agardhii. P. agardhii then prevailed in the phytoplankton until the end of the experiment, as it had in the fishpond in 2004, prior to the PAX-18 treatment (Fig. 3).

\section{Discussion}

Previous reports on the PAX-18 coagulant have dealt mainly with its influence on environmental variables in large, deep lakes and phytoplankton communities were usually evaluated only as chlorophyll- $a$ concentrations (GAWROŃSKA et al. 2002, GaWroŃsKa \& BrozowsKa 2002, Lossow et al. 2002). The same situation is in the case of other coagulants (HANSEN et al. 2003, LeWANDOWSKI et al. 2003, Reitzel et al. 2003, Reitzel et al. 2005). As far as we know, there are no studies focused on the influence of aluminium coagulants on phytoplankton structure in small, shallow fishponds. However, the influence of the PAX-18 coagulant on selected environmental variables in the Bílá Lhota fishpond is in agreement with studies from Poland (GAWrońsKa et al. 2002, GawrońsKa \& BrozowsKa 2002, Lossow et al. 2002).

The PAX-18 coagulant has mostly been used for lake restoration by phosphorus precipitation and its high efficiency in phosphorus removal from the water column and in limiting the internal loading has been proved (GAWROŃSKA et al. 2002). Phosphates are precipitated in the form of insoluble complexes aluminiumhydroxide-phosphates, forming a barier on the sediment surface that effectively prevents phosphates release. The complexes are strong even in anaerobic conditions (WELCH et al. 1988). Similar effect was described for other aluminium 
coagulants (HANSEN et al. 2003, LewANDOwSKi et al. 2003, Reitzel et al. 2003, Reitzel et al. 2005). In the case of the Bílá Lhota fishpond the PAX-18 coagulant was used for prevention of phosphate release from bottom sediments and removal of phytoplankton organisms from the water column by their coagulation, aggregation and sedimentation. Because of simultaneous precipitation of phosphorus and coagulation of organic matter and particles (organisms), the estimation of optimum coagulation dose has to be based on laboratory coagulation tests done closely before the coagulant application into the water body. Results of these tests depend on the particular algal assemblage. For example, our laboratory experiments showed that some species can escape from flocs back to the water column even after addition as high a dose of $\mathrm{Al}$ as 1100 $\mu$ mol. $1^{-1}$.

Planktothrix agardhii (Gomont) ANAGn. et KOMÁREK was found to be the dominant species in $40 \%$ of Czech fishponds (HAŠLER \&PoulíčKOVÁ 2003). This species (formerly Oscillatoria agardhii) is considered to be the most important bloom-forming species in temperate shallow lakes (SCHEFFER et al. 1997). P. agardhii is able to tolerate very low light intensities, but exhibits a high demand for phosphorus HAšLER et al. (2003). The timing of cyanobacterial blooms in late summer is sometimes thought to be connected with favoring a lower N/P ratio (SмiтH 1983). In general, heterocystous (nitrogen fixing) cyanobacteria (Anabaena, Aphanizomenon) gain advantage under conditions of $\mathrm{N}$ limitation (BULGAKOV \& Levich 1999, Reynolds 1999). Although $P$. agardhii is not a heterocystous cyanobacterium, it is probably able to create diazocytes, nitrogen fixing metamorphosed vegetative cells (Prof. J. KOMÁREK, personal communication).

The Bílá Lhota fishpond is a shallow eutrophic pond with average summer temperatures near $20^{\circ} \mathrm{C}$. Light conditions in the water column are low (average values in summer: surface $=$ $136.8 \mathrm{~W} \cdot \mathrm{m}^{-2}$, depth $20 \mathrm{~cm}=4.8 \mathrm{~W} \cdot \mathrm{m}^{-2}$ ) due to the small total area, shading by surrounding trees and dense water blooms. The population of Planktothrix agardhii had persisted in the fishpond throughout the whole year for several years, as it had in several other localities (BERGER 1975, SAS 1989). The annual cycle of $P$. agardhii starts in March with the germination of hormogonia. Abundance and biomass of $P$. agardhii increase during the season with the maximum in August.
The population overwinters near the pond bottom in the form of hormogonia $(60 \%)$ and filaments (40\%) (PoulíčKovÁ et al. 2004). The same abundance and seasonal dynamics of $P$. agardhii were observed in the control enclosures in 2005 (Fig. 2) as in the fishpond in 2004 (Fig. 5). By contrast, a significant decrease in $P$. agardhii abundance was achieved in the fishpond water in 2005 under PAX-18 treatment (Fig. 1). Total phosphorus, phosphate ions and chlorophyll- $a$ in the fishpond water were higher in 2004 than in 2005. The opposite situation was in the case of the N/P ratio (2004: 7:1 - 14:1, 2005: 14:1 40:1, unpublished data). Phosphorus decrease and higher N/P ratio probably led to changes in the phytoplankton composition in the fishpond in 2005. By contrast, phosphorus release from the sediment resulted in lower N/P ratio in the control enclosures. The N/P ratio was lower than in the fishpond from May 2005 onwards and high phosphorus concentration probably supported $P$. agardhii persistence in the control enclosures. With regard to above mentioned high demand of $P$. agardhii for phosphorus, we think that Planktothrix dominance in the control enclosures was enabled by high phosphorus concentration and not by nitrogen limitation (low N/P ratio) as assumed in previously published hypothesis (e.g. SMITH 1983). According to REYNOLDS (1999), it is the nutrients themselves, each and individually, that are potentially crucial for species composition of the freshwater phytoplankton and not the N/P ratio.

After the restoration, the fishpond was without cyanobacterial bloom in the summer. Assessment of long-term results of the fishpond treatment will be possible after further studies carried out in following years. Our results support the idea of possible use of the polyaluminium chloride coagulant for fishpond restoration practice. The associated changes in chemistry of the treated water body, i.e. increase in chlorides concentration and also a very short increase in dissolved aluminium concentration, shall be taken into account. The negative influence on other biota in the treated system shall be also assessed and taken into account before the decision on any full scale treatment is made. Especially the influence of particles (flocs) formed after coagulant addition on filtration rate of zooplankton should be considered. 


\section{Acknowledgements}

The authors are grateful to Kemwater ProChemie (The Czech Republic) for financial support and the coagulant PAX-18 providing. We also thank administration of the Forest Garden Bílá Lhota for permission for the research and Dr. Martyn Kelly, Bowburn Consultancy, UK, for improving the English. This work was supported by the GAČR 522/03/0323 project.

\section{References}

Anonymous (1992): HACH DR/2000 Spectrophotome-ter Handbook. - 560 pp., HACH Company, Loveland.

Berger, C. (1975): Occurrence of Oscillatoria agardhii Gomont in some shallow eutrophic lakes. - Verh. Int. Verein. Limnol. 19: 1689-1697.

Bulgakov, N. G. \& Levich, A. P. (1999): The nitrogen:phosphorus ratio as a factor regulating phytoplankton community structure. - Arch. Hydrobiol. 146: 3-22.

GawrońsKa, H. \& BrozowsKa, R. (2002): Influence of the PAX coagulant application on internal loading in Lake Długie. - Limnological Review 2: 111-119.

GawrońsKa, H., Lossow, K. \& GrochowsKa, J. (2002): Influence of the aluminium coagulant PAX on the aquatic enviroment of Lake Długie in Olsztyn. Limnological Review 2: 121-130.

HašLer, P. \& PoulíčKovÁ, A. (2003): Diurnal changes in vertical distribution and morphology of a natural population of Planktothrix agardhii (Gom.) Anagnostidis et Komárek (Cyanobacteria). Hydrobiologia 506-509: 195-201.

Hašler, P., PoulíčKovÁ, A. \& VAR̆eKová, Š. (2003): Comparative studies on two strains of the genus Planktothrix (Cyanophyta, Cyanoprokaryota). Algological Studies 108: 31-43.

Hansen, J., Reitzel, K., Jensen, H. S. \& Andersen, F.Ø. (2003): Effects of aluminium, iron, oxygen and nitrate additions on phosphorus release from the sediment of a Danish softwater lake. Hydrobiologia 492: 139-149.

KIRK, R. E. (1982): Experimental design: procedures for the behavioral science. - 911 pp., Brooks/Cole. Pacific Grove, California.

KoříneK, V., Fott, J., Fuksa, J., Lellák, J. \& PražÁková, M. (1987): Carp ponds of central Europe. - In: MichAEL, R.G. (ed.): Managed Aquatic Ecosystems, 29-62 pp., Elsevier Science Publisher B. V., Amsterdam.

Lelková, E., Rulík, M., Hekera, P., Dobiáš, P. \& Dolejš, P. (2005): Použití koagulantu PAX-18 v podmínkách malého hypertrofního rybníka: Zkušenosti a první výsledky [Using of the PAX-18 coagulant in a small hypereutrophic fishpond: Experience and first results]. - Vodní hospodářství 9: 252-254.

Lewandowski, J., Schauser, I. \& Hupfer, M. (2003): Long term effects of phosphorus precipitations with alum in hypereutrophic Lake Süsser See (Germany). Water Res. 37: 3194-3204.

Lossow K., GawrońsKa, H. \& Łopata, M. (2002): Preliminary restoration results of Lake Głeboczek in Tuchola by phosphorus inactivation with polyaluminium chloride (PAX). - Limnological Review 2: 265-273.
LysákovÁ, M., Kitner, M. \& PoulíčKovÁ, A. (2007): The epipelic algae of fishponds of Central and Northern Moravia (The Czech Republic). - Fottea 7(1): 69 -75 .

Mehner, T., Kasprzak, P., Wysujack, K., Laude, U. \& Koschel, R. (2001): Restoration of a stratified lake (Feldberger Haussee, Germany) by a combination of nutrient load reduction and long-term biomanipulation. Int. Rev. Hydrobiol. 86: 253-265.

Pechar, L. (1987): Use of the acetone-methanol mixture for extraction and spectrophotometric determination of chlorophyll $a$ in phytoplankton. - Algological Studies 78: $99-117$.

PoulíčKovÁ, A., HašLer, P. \& Kitner, M. (2004): Annual cycle of Planktothrix agardhii (Gom.) Anagn. \& Kom. Nature Population. - Int. Rev. Hydrobiol. 89: $278-288$.

Reitzel, K., Hansen, J., Andersen, F. Ø., Hansen, K. S. \& JeNSEN, H. S. (2005): Lake restoration by dosing aluminium relative to mobile phosphorus in the sediment. - Environ. Sci. Technol. 39: 4134-4140.

Reitzel, K., Hansen, J., Jensen, H. S., Andersen, F. Ø. \& HaNSEN, K. S. (2003): Testing aluminium addition as a tool for lake restoration in shallow, eutrophic Lake Sønderby, Denmark. - Hydrobiologia 506-509: 781-787.

Reynolds, C. S. (1999): Non-determinism to Proba-bility, or $\mathrm{N}: \mathrm{P}$ in the community ecology of phytoplankton. Arch. Hydrobiol. 146: 23-35.

SAS, H. (1989): Lake restoration by reduction of nutrient loading: expectations, experience, extrapolations. 497 pp., Academia Verlag Richartz, St. Augustin.

Scheffer, M., Rinaldi, S., Gragnani, A., Mur, L. R. \& Van NES, E. H. (1997): On the dominance of filamentous cyanobacteria in shallow, turbid lakes. - Ecology 78 : 272-282.

Sмith, V. H. (1983): Low nitrogen to phosphorus ratios favor dominance by blue-green lgae in lake phytoplankton. - Science 221: 669-671.

STRAŠKRABA, M. (1986): Ecotechnological measures against eutrophication. - Limnologica 17: 237-249.

Welch, E. B., DeGasperi, C. L., Spyridakis, D. E. \& Belnick, T. J. (1988): Internal phosphorus loading and alum effectivness in shallow lakes. - Lake Reserv. Manage. 4: 27-34.

Wolter, K.-D. (1994): Phosphorus precipitation. - In: EiseltovÁ, M. (ed.): Restoration of lake ecosystems-a holistic approach, 63-68 pp., International Waterfowl and Wetlands Research Bureau, Gloucester.

(C) Czech Phycological Society

Received March 28, 2007

Accepted November 5, 2007 